Revisão / Review

\title{
A relevância das células natural killer (NK) e killer immunoglobulin-like receptors (KIR) no transplante de células-tronco hematopoéticas (TCTH) \\ The relevance of natural killer (NK) cells and killer immunoglobulin-like receptors (KIR) in hematopoietic stem cell transplantation (HSCT)
}

Aline Almeida-Oliveira

Hilda R. Diamond

\begin{abstract}
As células natural killer (NK) foram identificadas há mais de 30 anos por sua capacidade de matar células tumorais e infectadas por vírus sem precisar de sensibilização prévia. No entanto, a forma como as células NK matam seus alvos ficou desconhecida por muito tempo. Na década de 90, a partir de várias observações, foi proposto que as células NK matariam células com a expressão diminuída de antígeno leucocitário humano (HLA), protegendo as células autólogas normais, o que ficou conhecido como hipótese do missing-self. Esta teoria foi confirmada através da descoberta de vários receptores, principalmente os da família killer immunoglobulin-like receptors (KIR), que reconhecem moléculas de HLA de classe I. Estes novos conceitos levaram à busca da importância dos receptores KIR no transplante de células-tronco hematopoéticas (TCTH). Foi sugerido que as disparidades de HLA entre o doador e o paciente poderiam ser reconhecidas por células NK levando à aloreatividade, o que ajudaria no efeito enxerto contra leucemia. No entanto, apesar de alguns resultados promissores, até hoje, os diferentes estudos sobre o assunto não chegaram a um consenso. Nesta revisão, será abordada a relevância das células $N K$ e dos receptores KIR nos diferentes tipos de TCTH. Rev. bras. hematol. hemoter. 2008;30(4):320-329.
\end{abstract}

Palavras-chave: KIR; células NK; transplante de células-tronco hematopoéticas; leucemia.

\section{Introdução}

O transplante de células-tronco hematopoéticas (TCTH) alogeneico é um tratamento bem estabelecido e tem sido muito utilizado como estratégia curativa para uma variedade de doenças hematológicas malignas associadas a um mau prognóstico com a quimioterapia convencional ou que continuaram progredindo após uma resposta inicial à quimioterapia. ${ }^{1}$

$\mathrm{Na}$ última década, o paradigma do tratamento de leucemias por TCTH mudou. O foco inicial era utilizar doses mieloablativas de radiação e quimioterapia para eliminar a leucemia, e o transplante era realizado para prevenir a morte por falha da medula óssea. Atualmente, o enfoque do TCTH alogeneico consiste em um regime de condicionamento com baixas doses de quimioterapia e radioterapia, suficientes apenas para permitir o enxerto das células-tronco hematopoéticas do doador. Neste modelo de transplante mais atual, as células aloimunes de origem do doador é que são responsáveis por erradicar as células leucêmicas, no chamado efeito enxerto contra leucemia (ECL), como uma forma de imunoterapia adotiva. ${ }^{2}$

Recentemente foi demonstrado que as células natural killer (NK) participam como mediadoras deste efeito, e o interesse no potencial antileucêmico destas células tem crescido nos últimos anos. ${ }^{3,4}$ Essas células são as primeiras a se recuperarem após o TCTH e são capazes de mediar a resposta imune inicial, já que a recuperação das células $\mathrm{T}$ é mais tardia. ${ }^{5,6}$

Laboratório de Imunologia - Centro de Transplante de Medula Óssea (Cemo) - Instituto Nacional de Câncer - Rio de Janeiro-RJ

Correspondência: Hilda Rachel Diamond

Praça da Cruz Vermelha, $n^{\circ} 23-6^{\circ}$ andar

Divisão Laboratorial - Laboratório de Imunologia

20230-130 - Rio de Janeiro-RJ - Brasil

Tel.: 5521 2506-6866 / 5521 2506-6697 / 552196078062

E-mail: hdiamond@inca.gov.br 
As células NK são importantes componentes do sistema imune inato e têm a capacidade de lisar células alvo, além de fornecer citocinas imunoregulatórias. ${ }^{7,8,9}$ As células NK, como outras células do sistema imune inato, utilizam uma estratégia de reconhecimento do alvo através de múltiplos receptores. Estes receptores podem gerar sinais ativadores ou inibidores e a atividade citotóxica destas células é regulada pelo equilíbrio dos sinais gerados pela ligação destes receptores a moléculas específicas nas células alvo.,10

Os receptores de células NK melhor caracterizados e estudados pertencem à família killer immunoglobulin-like receptor (KIR). Estas moléculas se apresentam como conjuntos de receptores ativadores e inibidores pareados que primariamente reconhecem as moléculas de HLA-A, B e C..$^{11,12}$

Foi demonstrado que a ausência de ligantes de HLA no paciente para receptores KIR inibidores do doador (incompatibilidade KIR) pode estar relacionada ao efeito ECL e à doença enxerto contra o hospedeiro (DECH). Este tipo de estudo foi iniciado por um grupo de pesquisadores italianos no TCTH haploidêntico, no qual foi demonstrado que a incompatibilidade KIR levava à geração de clones de células NK aloreativos, causando melhora na sobrevida dos pacientes. Este efeito foi observado em casos de leucemia mielóide aguda (LMA), mas não de leucemia linfóide aguda (LLA). ${ }^{13-15}$ A partir destas observações, um grande número de estudos demonstrou efeitos benéficos ou deletérios da incompatibilidade de ligantes KIR em vários tipos de TCTH. Neste trabalho será revisada a importância das células NK e dos receptores KIR nos diferentes tipos de TCTH.

\section{As células natural killer (NK) no transplante de células-tronco hematopoéticas (TCTH)}

Recentemente foi demonstrado que as células natural killer (NK) participam como mediadoras do ECL e o interesse no potencial antileucêmico destas células tem crescido nos últimos anos..$^{3,4}$

Desde a década de 80 , as células NK foram consideradas como a primeira linha de defesa contra células tumorais. Nesta época, foi demonstrado que estas células tinham atividade citotóxica contra diversos tipos de leucemias, tanto células primárias quanto linhagens estabelecidas. Diferentes leucemias parecem apresentar suscetibilidades distintas à atividade citotóxica das células NK, mas ainda não há um consenso sobre qual tipo de leucemia seria mais susceptível. ${ }^{16,17,18}$

As células NK são importantes componentes do sistema imune inato e têm a capacidade de lisar células alvo, além de fornecer citocinas imunoregulatórias. As principais citocinas produzidas por estas células incluem: interleucina 3 (IL-3), fator de estimulação de colônia de macrófago e granulócito (GM-CSF), fator beta de transformação do crescimento (TGF- $\beta$ ), interferon gama (IFN- $\gamma$ ) e fator de necrose tumoral alfa $(\mathrm{TNF}-\alpha)^{7,8}$
Essas células são as primeiras a se recuperarem após o TCTH e são capazes de mediar a resposta imune inicial, já que a recuperação das células $\mathrm{T}$ é mais tardia., ${ }^{5,6}$ Além da capacidade de promover o ECL, estas células são capazes de prevenir a DECH, conforme demonstrado nos transplantes em modelos animais e em humanos. ${ }^{14,19}$

A DECH é uma doença sistêmica de rápida progressão, caracterizada por imunossupressão e injúria de tecidos em vários órgãos como fígado, pele e mucosa intestinal. A destruição destes tecidos resulta em erupções cutâneas, denudação da mucosa e diarréia. Apesar do progresso no entendimento dos mediadores envolvidos na $\mathrm{DECH}$, o tratamento efetivo contra esta doença continua elusivo. A maioria dos pacientes que desenvolvem manifestações severas desta doença acaba sucumbindo a ela ou a complicações de seus tratamentos. ${ }^{20}$

Foi montado um modelo experimental de DECH em camundongos em que era feito um TCTH completamente incompatível acrescido de células T do doador. Neste modelo, foi examinado se a transferência adotiva de células NK do doador ativadas com IL-2 poderia prevenir a DECH sem comprometer o efeito antitumoral. Observou-se um efeito protetor contra a DECH. Este efeito ocorreu quando as células NK foram infundidas no dia do TCTH, mas não quando a infusão ocorria de forma mais tardia. Estes resultados indicaram que as células NK tiveram a capacidade de suprimir o estágio de sensibilização da DECH no momento em que as células T do doador estavam reagindo pela primeira vez contra aloantígenos do hospedeiro. Acredita-se que as células NK não sejam capazes de iniciar a $\mathrm{DECH}$, entretanto elas podem ter um papel na patogenia da doença quando já iniciada por células $\mathrm{T}$ do doador. ${ }^{19}$

Neste mesmo estudo, foi demonstrado que, enquanto a infusão de células $\mathrm{T}$ levou a um aumento do efeito antitumoral e à indução da $\mathrm{DECH}$, as células NK alogeneicas ativadas foram capazes de inibir a DECH e, ao mesmo tempo, promover o efeito antitumoral. Este efeito foi observado através de um aumento na sobrevida e um menor número de metástases no pulmão dos animais onde as células NK eram infundidas com o TCTH e células T alogeneicas. Os animais que recebiam apenas o TCTH com as células T alogeneicas apresentavam diminuição no número de metástases de pulmão, mas em menor grau em comparação com aqueles que recebiam células NK ativadas. Além disso, estes camundongos morriam de $\mathrm{DECH}$. Este estudo levou à sugestão de que era possível separar o ECL da DECH a partir das células NK. ${ }^{19}$

Um outro estudo sobre o papel das células NK no ECL foi realizado por Ruggeri et al. ${ }^{13} \mathrm{em}$ pacientes submetidos ao TCTH haploidêntico. Estes autores partiram da teoria do missing-self, em que as células NK, apesar de tolerantes com as células autólogas normais, conseguem reconhecer e atacar células que tenham baixa expressão de HLA classe I. ${ }^{21}$ Neste tipo de transplante o alto grau de incompatibilidade de HLA poderia levar a aloreatividade das células NK do doa- 
dor contra o paciente. De fato, foi demonstrada a presença de clones de células NK aloreativos quando havia determinadas diferenças de HLA entre o doador e paciente. Estes clones eram capazes de lisar células leucêmicas do paciente, sendo as LMA mais susceptíveis que as LLA. Estes clones também reagiram contra linhagens geradas a partir de linfócitos normais do paciente..$^{13}$

Mais tarde, num outro estudo realizado por este grupo em TCTH haploidêntico, os pacientes foram divididos em dois grupos: o grupo 1 consistiu em pares pacientes-doadores em que não havia presença de células NK aloreativas; e o grupo 2, em pares pacientes-doadores com a presença das células NK aloreativas. A presença destas células levou à diminuição do risco de recaída nos casos de pacientes com LMA ( $75 \%$ de probabilidade de recaída em cinco anos no grupo 1 contra $0 \%$ no grupo 2). No entanto, este efeito não foi observado nos pacientes com LLA ( $90 \%$ de probabilidade de recaída em cinco anos no grupo 1 contra $85 \%$ no grupo 2). Nos casos de LMA, também houve melhora da sobrevida livre de doença (no grupo 1 , a probabilidade de sobrevida em cinco anos era $5 \%$ contra $60 \%$ no grupo 2). A presença de células NK aloreativas também levou à diminuição da rejeição do enxerto $(15 \%$ no grupo 1 contra $0 \%$ no grupo 2). ${ }^{14}$

A partir desses resultados em TCTH haploidênticos realizados em seres humanos, assim como em modelos animais e ensaios in vitro, ficou estabelecido que as células NK aloreativas eram capazes de promover o ECL (por lisar as células leucêmicas do paciente) e promover o enxerto (por matar as células-tronco hematopoéticas normais residuais do paciente, mas não de outros tecidos normais). Além disto, foi elucidado que as células NK aloreativas são capazes de prevenir a DECH através da lise de células apresentadoras de antígeno do paciente. ${ }^{13-15}$ Estes efeitos estão representados na Figura 1.

Nestes dois estudos, a geração de clones aloreativos só ocorre quando há diferenças de HLA entre doador e paciente em epítopos reconhecidos pelos receptores da família KIR do doador.

\section{Família killer immunoglobulin-like receptor (KIR)}

A principal família de receptores de células NK que participa do missing-selfé conhecida como KIR. Estas moléculas se apresentam como conjuntos de receptores ativadores e inibidores pareados que, primariamente, reconhecem moléculas de HLA-A, B e C nas células alvo. ${ }^{11,12} \mathrm{~A}$ expressão de genes KIR é restrita às células NK e células $\mathrm{T}$ CD8 de memória. ${ }^{22}$

Os receptores da família KIR são designados pelo número de domínios (D) de imunoglobulinas (KIR2D e KIR3D).

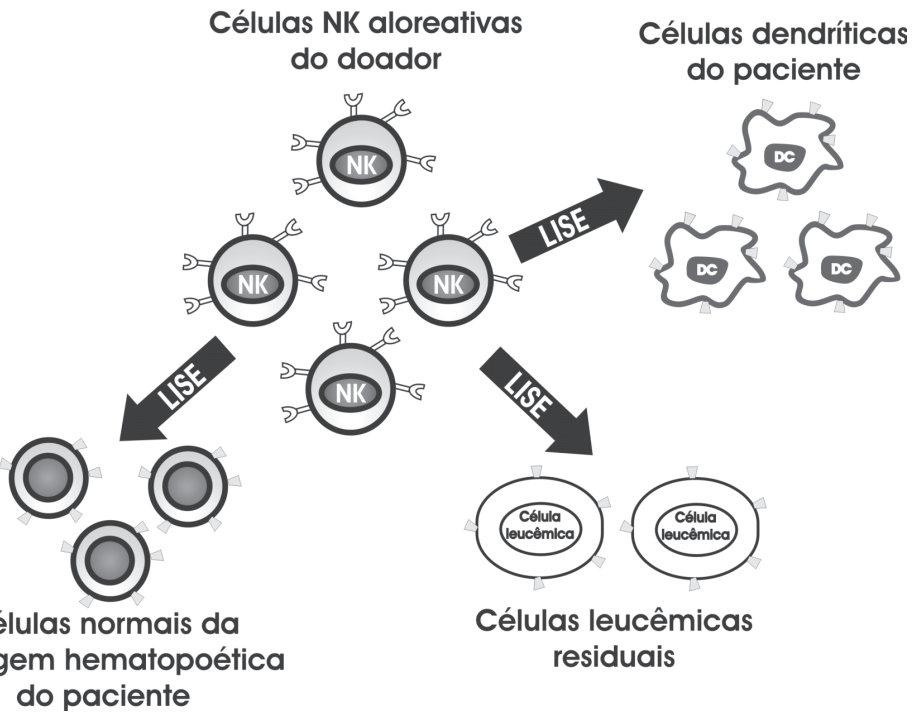

gura 1. A aloreatividade de células NK no TCTH haploidêntico: efeito ECL, através de células hematopoéticas normais, e prevenção da DECH, através de lise de

Sua função ativadora ou inibidora é determinada pelo tamanho de sua cauda citoplasmática, curta (representada por $\mathrm{S}$, ex: KIR2DS1) ou longa (representada por L, ex. KIR2DL1). Os receptores inibitórios possuem cauda intracitoplasmática longa, pois geram sinal através de domínios immunoreceptor tyrosine-based inhibitory motif (ITIM), que fazem parte da estrutura protéica destes receptores. Por outro lado, os receptores ativadores apresentam cauda intracitoplasmática curta, não possuindo domínios capazes de mediar sinal em sua estrutura protéica e por isto estão associados a moléculas adaptadoras (ex: DAP-12) que possuem domínios immunoreceptor tyrosine-based activating motif (ITAM) para poder gerar o sinal ativador. ${ }^{23,24}$ (Figura 2)

Até o momento, foram descritos 14 genes da família KIR e 2 pseudogenes. Estes genes estão localizados no cromossoma 19 na região q13.4. Dez destes genes codificam receptores com dois domínios de imunoglobulina, genes KIR2D, e quatro possuem três domínios de imunoglobulina, genes KIR3D. 7,11,25

Os ligantes para o receptor KIR considerados mais importantes são alelos de HLA-C. Os receptores KIR reconhecem dois grupos distintos de HLA-C, cuja diferença está no dimorfismo de aminoácidos na posição 77. O grupo 1 de epítopos de HLA-C apresenta serina na posição 77 (Cw1, w3, w7, w8 e outros alelos relacionados) e são reconhecidos por KIR2DL2 e KIR2DL3. As moléculas do grupo 2 de HLA-C possuem asparagina na posição $77(\mathrm{Cw} 2, \mathrm{w} 4, \mathrm{w} 5$, w6 e outros alelos relacionados) e são reconhecidos por KIR2DL1. Outro receptor KIR cujo ligante está bem definido é o KIR3DL1, que reconhece o epítopo de HLA-B Bw4 (B*08, $13,27,44,51,52,53,57$ e 58$)$. Os outros KIR inibidores têm especificidades menos definidas, como KIR3DL2, que re- 


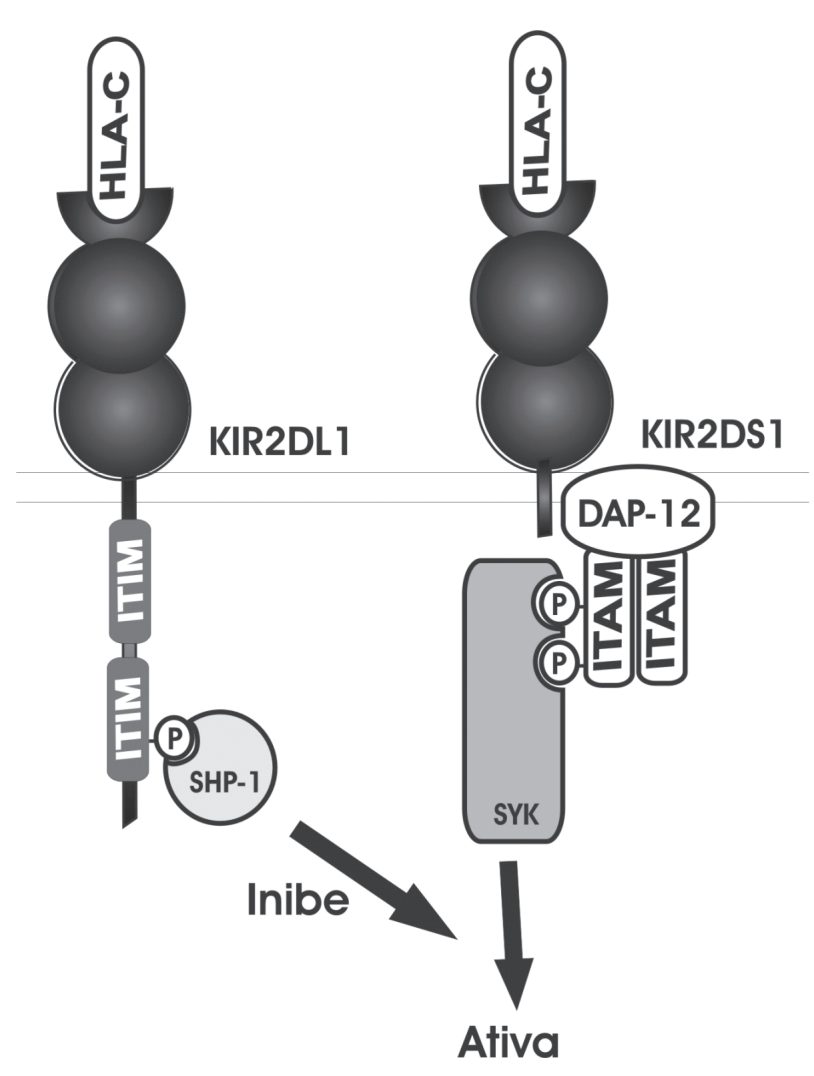

Figura 2. Na figura à esquerda é mostrado um exemplo de um receptor inibidor (KIR2DL) que apresenta os domínios de ITIM como parte de sua cauda intracitoplasmática e iniciam a sinalização inibitória. À direita é mostrado um exemplo de um receptor ativador (KIR2DS) que utiliza uma molécula adaptadora (DAP-12) com domínios de ITAM para gerar sinal ativador

conhece algumas variantes de HLA-A (A3, A11), ou não têm nenhum ligante conhecido até o momento. O KIR2DL4 apresenta cauda intracitoplasmática longa, porém evidências recentes mostram que a ligação deste receptor a HLAG em células NK em repouso resulta numa ativação que leva à produção de IFN- $\gamma$ sem atividade citotóxica. ${ }^{7,11,26}$

Apesar de alguns receptores KIR ativadores apresentarem uma estrutura de reconhecimento do ligante muito semelhante a receptores inibidores, como no par 2DL1/2DS1 e no trio de 2DL2/2DL3/2DS2, a afinidade de ligação das variantes ativadoras é fortemente reduzida em comparação às variantes inibidoras. Por isso, quando há ligação de receptores inibidores e ativadores ao mesmo tempo, acredita-se que o sinal inibidor prevaleça. Ainda não foram definidos os ligantes dos outros KIR ativadores. ${ }^{7,25}$ A Tabela 1 apresenta todos os receptores KIR e seus ligantes identificados até o momento.

Foi observado que o número e a composição de genes KIR podem variar entre diferentes indivíduos. Isto levou à descrição de dois grupos de haplótipos KIR, designados A e B. Os haplótipos do grupo A não possuem outros genes KIR ativadores além do KIR2DS4 e apresentam os genes inibidores
Tabela 1. Receptores KIR e seus ligantes conhecidos

\begin{tabular}{|c|c|c|}
\hline \multirow{8}{*}{ 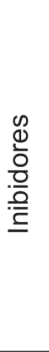 } & Receptor & Especificidade de ligante \\
\hline & KIR2DL1 & Grupo 2 de HLA-C \\
\hline & KIR2DL2 & Grupo 1 de HLA-C \\
\hline & KIR2DL3 & Grupo 1 de HLA-C \\
\hline & KIR2DL5 & Não definido \\
\hline & KIR3DL1 & HLA-Bw4 \\
\hline & KIR3DL2 & A3, A11 e outros não definidos \\
\hline & KIR3DL3 & Não definido \\
\hline \multirow{7}{*}{ 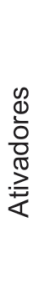 } & KIR2DS1 & Grupo 2 de HLA-C \\
\hline & KIR2DS2 & Grupo 1 de HLA-C \\
\hline & KIR2DS3 & Não definido \\
\hline & KIR2DL4 & HLA-G \\
\hline & KIR2DS4 & Não definido \\
\hline & KIR2DS5 & Não definido \\
\hline & KIR3DS1 & Não definido \\
\hline
\end{tabular}

KIR2DL1, KIR2DL3 e KIR3DL1. Outros quatro genes KIR estão presentes em todos os haplótipos, tanto do grupo A quanto do B, com raras exceções. São os genes KIR3DL3, KIR3DL2, KIR2DL4 e KIR3DP1 (DP - pseudogene). Os haplótipos do grupo A não variam em conteúdo de genes, mas têm grande variação no nível alélico, enquanto os do grupo B têm alta variação no conteúdo de genes, mas possuem polimorfismo alélico apenas moderado. Os haplótipos $\mathrm{B}$ apresentam mais genes que o do grupo $\mathrm{A}$, incluindo o KIR2DL5, assim como várias possíveis combinações de genes ativadores. ${ }^{22,25}$

Além do polimorfismo e da variação do conteúdo de genes KIR de indivíduo para indivíduo, a expressão dos genes KIR também varia de célula NK para célula NK dentro do mesmo indivíduo, ou seja, os KIR têm uma distribuição clonal nas células NK. Com poucas exceções, todos os genes KIR presentes no genoma de um indivíduo são expressos em sua população de células policlonal. Entretanto, os clones individuais de células NK expressam apenas alguns genes KIR, aparentemente em combinações estocásticas que são reguladas principalmente no nível de transcrição e são mantidas de forma estável. Os mecanismos moleculares que regulam a expressão e distribuição celular de KIR ainda são desconhecidos. $^{22}$

\section{Os receptores KIR e a aloreatividade}

Enquanto os genes KIR estão localizados no cromossoma 19, os genes de seus ligantes, HLA, estão localizados no cromossoma 6, fazendo com que a herança de KIR e HLA não seja pareada. Dessa forma, muitos indivíduos apresentam genes KIR inibidores para os quais não há ligantes de HLA e vice-versa. Como a expressão dos receptores de células NK se faz de maneira randômica, teoricamente, podem surgir clones auto-reativos, mas uma variedade de estu- 
dos demonstrou que ocorre tolerância ao próprio. Os processos envolvidos neste evento ainda não são bem entendidos. ${ }^{27,28}$ Foi demonstrado tanto em modelo murino quanto em seres humanos que a tolerância ao próprio ocorre pela aquisição de um fenótipo funcional hiporresponsivo, similar ao conceito de anergia aceito para as células B e T. ${ }^{29,30}$

As células NK são claramente autotolerantes, porém podem ser aloreativas contra células de outros indivíduos. Elas serão aloreativas contra células de indivíduos que não têm expressão de moléculas de HLA que servem como ligantes para seus KIR inibitórios. Isto é conhecido como incompatibilidade KIR. Inversamente, as células NK de um indivíduo são tolerantes com células de outros indivíduos que tenham os HLA que servem como ligantes para os KIR inibitórios, ou seja, quando houver compatibilidade KIR. ${ }^{7,13}$ Estas duas situações estão representadas na Figura 3. Ainda não está claro qual o papel dos receptores KIR ativadores na aloreatividade.

Esta aloreatividade pode ser prevista de duas manei-
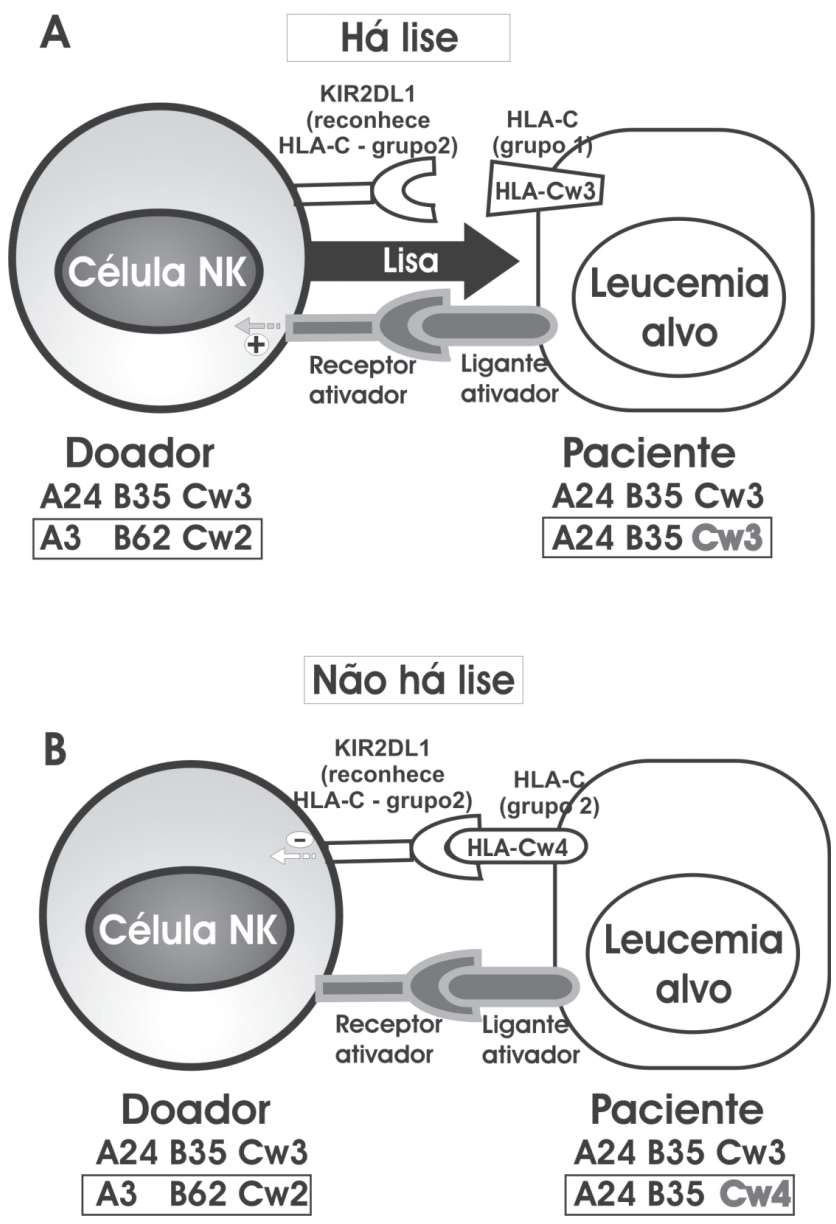

Figura 3. Potencial aloreativo de células NK. Em (A) o paciente não possui ligantes de HLA para receptores KIR do doador levando a lise da célula alvo. Em (B) o paciente possui ligantes para os KIR inibidores do doador, portanto não há potencial aloreativo ras. Alguns estudos reduzem a análise à compatibilidade de epítopos de HLA, ignorando a análise direta do repertório KIR. Neste tipo de estudo, a aloreatividade é prevista nos casos em que o doador possui HLA-C do grupo 1 e o paciente do grupo 2, ou doador do grupo 2 e paciente do grupo 1. Outra possibilidade é com relação a Bw4. Se o doador possuir Bw4 e o paciente não tiver este tipo de HLA-B, considera-se que este doador possui potencial aloreativo contra o paciente. Este tipo de estudo pode ser referido como modelo ligante-ligante, já que não é feita uma análise direta do receptor KIR. Este modelo já contém cerca de $10 \%$ de erro embutido, já que a chance de prever o repertório KIR pela análise de ligantes de HLA é de cerca de $90 \%$. Num outro tipo de estudo, considerado um modelo mais sofisticado, além da análise de incompatibilidade de HLA, o repertório KIR do doador é analisado diretamente, de forma que a incompatibilidade KIR só é considerada presente quando a análise do repertório KIR do doador confirmar a presença de receptores KIR para os quais o paciente não possui ligante. Este modelo mais específico é conhecido como modelo receptor-ligante. ${ }^{28}$

Estes dois modelos têm sido utilizados para estudar o potencial aloreativo das células NK no TCTH.

\section{A incompatibilidade KIR e o TCTH}

Para estudar a aloreativadade das células NK no TCTH, uma questão importante é saber como ocorre a recuperação do repertório KIR após o transplante, pois se os pacientes mantiverem o repertório KIR semelhante ao do doador, a aloreatividade das células NK pode causar um efeito mais prolongado, pois não será dependente apenas das células NK do doador infundidas no momento do transplante, mas também das células NK que serão recuperadas no paciente. Por outro lado, se a recuperação das células NK for influenciada pelo ambiente de HLA do hospedeiro, as células NK aloreativas terão uma vida curta. Até o momento foram realizados alguns estudos sobre a recuperação KIR após o TCTH HLA idêntico e haploidêntico e foi demonstrado que o repertório KIR recuperado é semelhante ao do doador, sugerindo que seja possível um potencial aloreativo a longo prazo, porém é necessária a continuidade destes estudos para confirmar este efeito. ${ }^{28,31,32}$

O estudo do papel da incompatibilidade KIR no transplante foi iniciado por um grupo de pesquisadores italianos no TCTH haploidêntico, no qual demonstrou-se que a incompatibilidade KIR levava à geração de clones de células NK aloreativos, causando uma menor incidência da DECH através da lise de células apresentadoras de antígenos, aumento no efeito ECL através de lise de células leucêmicas residuais e a melhora da sobrevida dos pacientes. ${ }^{13-15}$

A partir destas observações, um grande número de estudos demonstrou efeitos benéficos ou deletérios da incompatibilidade de ligantes KIR em vários tipos de TCTH (Tabela 2). A interpretação mais parcimoniosa destes dados 
conflitantes é que o efeito da incompatibilidade KIR é dependente dos protocolos de transplante, sendo que possivelmente a depleção de células T seja a variável mais importante. ${ }^{28}$

Embora o estudo da incompatibilidade KIR tenha começado no TCTH haploidêntico, até o momento foram realizados poucos estudos sobre este assunto. . $^{1,32,33}$

Leung et al. ${ }^{32}$ estudaram o papel da aloreatividade NK em TCTH haploidêntico com depleção de células T em crianças com LMA e LLA. Além do modelo ligante-ligante, foi estudado o modelo receptor-ligante através da detecção de expressão de KIR em superfície por citometria de fluxo e/ou detecção de transcritos KIR por biologia molecular. Foi demonstrado que o modelo receptor-ligante é mais preciso para detectar o grupo com maior risco de recaída. Neste modelo, a incompatibilidade KIR levou a menor taxa de recaída (Tabela 2). Enquanto Ruggeri et al. ${ }^{14}$ observaram melhoras nas taxas de recaídas apenas nos casos de LMA, Leung et al..$^{32}$ obtiveram melhora tanto dos casos de LLA quanto de LMA. Isso pode estar relacionado ao fato que Leung et al. ${ }^{32}$ estudaram crianças e Ruggeri et al. ${ }^{14}$ apenas adultos.

O outro estudo relativo ao papel das células NK aloreativas no TCTH haploidêntico realizado por Bishara et al. ${ }^{33}$ apresentou resultados bem distintos. Este grupo estudou 62 pacientes, incluindo casos de LLA, LMA e leucemia mielóide crônica (LMC). Foi utilizado apenas o modelo ligante-ligante e, ao invés de encontrar uma melhora no resultado do TCTH nos casos em que havia incompatibilidade KIR, houve uma considerável piora na sobrevida e maior incidência de DECH (Tabela 2). Os autores acreditam que este resultado negativo inesperado seja por diferenças no protocolo do TCTH, pois o regime de condicionamento foi menos citoredutor e a depleção de células $T$ menos eficaz em comparação com $o$ estudo de Ruggeri et al. ${ }^{14}$ Além disso, os pacientes do estudo de Bishara et al. ${ }^{33}$ apresentavam doenças mais agressivas, já que somente pacientes com características associadas a mau prognóstico fizeram parte deste estudo.

O papel da incompatibilidade KIR também foi avaliado em estudos de TCTH HLA-compatível não aparentado. Como os métodos mais acurados para detecção de HLA-C só foram desenvolvidos mais recentemente, muitos transplantes deste tipo podem contar com incompatibilidades do lócus $\mathrm{C}$ que não podiam ser detectadas anteriormente. A partir desta descoberta, começou-se a estudar se existe aloreatividade mediada por células NK neste tipo de transplante. ${ }^{28}$

O primeiro estudo em TCTH não aparentado foi realizado por Davies et al. ${ }^{34} \mathrm{e}$ apresentava pelo menos uma incompatibilidade de um alelo de HLA-A, -B, -C ou DRB1. O potencial aloreativo das células NK foi estudado através do modelo ligante-ligante em 175 pacientes com diversos tipos de leucemia, síndrome mielodisplásica (SMD) e outras doenças, entre adultos e crianças. Usando o modelo ligante-ligante, não foi encontrada nenhuma relação entre a incompatibilidade KIR e a incidência de DECH, chance de recaída ou pro- babilidade de sobrevida (Tabela 2). Neste estudo só houve depleção de células T em 35\% dos casos, e mesmo assim com uma eficiência muito menor do que a relatada por Ruggeri et $a l .{ }^{14} \mathrm{O}$ esquema de recuperação na presença de células $\mathrm{T}$ pode ter encoberto o potencial aloreativo das células NK. Além disso, por causa da presença de linfócitos T, foi necessária uma forte imunossupressão, que também pode ter influenciado o papel aloreativo das células NK. ${ }^{34}$

Outro grupo de pesquisadores estudou o papel da aloreatividade das células NK utilizando o modelo liganteligante em TCTH alogeneico não aparentado. Entre os 130 pacientes estudados, foram incluídos TCTH HLA-idêntico ou com pequeno grau de incompatibilidade de HLA. Foi observado um efeito benéfico na sobrevida livre de doença no grupo com incompatibilidade KIR. Os autores consideraram que houve também uma menor incidência de $\mathrm{DECH}$ e menor chance de recaída neste grupo, embora estes resultados não sejam estatisticamente significantes $^{35}$ (Tabela 2). Foi sugerido que o uso de globulina antitimócito (ATG) levou a uma depleção in vivo das células $T$, o que favoreceu o papel aloreativo das células NK no estudo de Giebel et al. ${ }^{35} \mathrm{em}$ comparação ao estudo de Davies et al. ${ }^{34}$

Bornhäuser et $a l .^{36}$, estudando o potencial aloreativo através do modelo ligante-ligante em 118 pacientes com doenças mielóides malignas, submetidos ao TCTH alogeneico não aparentado com HLA compatível ou com pequeno grau de incompatibilidade, encontraram resultados conflitantes com o de Giebel et al. ${ }^{35}$ pois a resposta do TCTH foi pior no grupo de incompatibilidade KIR. Embora estes pacientes também fizessem uso de ATG na profilaxia da DECH, não houve vantagem no grupo de incompatibilidade KIR com relação à incidência de $\mathrm{DECH}$ ou sobrevida. Com relação às chances de recaída, houve desvantagem no grupo de incompatibilidade KIR (Tabela 2). As discrepâncias observadas podem ser justificadas por diferenças nas características dos pacientes entre os estudos de Giebel et al. ${ }^{35}$ e de Bornhäuser $e t$ $a l .{ }^{36} \mathrm{O}$ estudo de Bornhäuser et al.$^{36}$ apresentou pacientes mais velhos, com maior incidência de DECH e com doenças em fases mais avançadas. Estes três fatores podem ter prejudicado a aloreatividade das células NK.

Um outro grupo de pesquisadores estudou a aloreatividade de células NK através do modelo ligante-ligante em TCTH alogeneico utilizando um protocolo de transplante homogêneo para todos os pacientes (regime de condicionamento mieloablativo, sem depleção de células T e sem uso de ATG), mas incluía doadores aparentados e não aparentados com HLA-idêntico ou pequenos graus de incompatibilidade. Foram estudados 374 pacientes com doenças mielóides malignas. Os pacientes foram divididos em três grupos: HLAidêntico, pequeno grau de incompatibilidade de alelos de HLA irrelevante ao KIR (na Tabela 2 este grupo é referido como HLA-não idêntico) e incompatibilidade KIR. No grupo com incompatibilidade KIR foi observado menor risco de recaída, porém não houve diferença com relação à inci- 
Tabela 2. Resumo dos resultados dos estudos publicados sobre o papel da incompatibilidade KIR no TCTH

\begin{tabular}{|c|c|c|c|c|}
\hline Estudo & Pacientes & Tipo de TCTH & $\begin{array}{l}\text { Resultado do grupo sem } \\
\text { incompatibilidade KIR }\end{array}$ & $\begin{array}{l}\text { Resultado do grupo KIR } \\
\text { incompatível }\end{array}$ \\
\hline $\begin{array}{l}\text { Ruggeri et al., } \\
2002^{14}\end{array}$ & $\begin{array}{l}\mathrm{N}=92, \\
57 \text { casos de LMA e } \\
35 \text { casos de LLA }\end{array}$ & $\begin{array}{l}\text { Haploidêntico com } \\
\text { depleção de células T }\end{array}$ & $\begin{array}{l}\text { DECH de } 13,7 \%^{*}, \\
\text { rec. de LLA de } 90 \% \text {, } \\
\text { rec. de LMA de } 75 \%{ }^{*} \text { e } \\
\text { SLD de } 5 \%^{*}\end{array}$ & $\begin{array}{l}\text { DECH de } 0 \%{ }^{*} \\
\text { rec. De LLA de } 85 \%, \\
\text { rec. de LMA de } 0 \%{ }^{*} \text { e } \\
\text { SLD de } 60 \%{ }^{*}\end{array}$ \\
\hline $\begin{array}{l}\text { Leung et al., } \\
2004^{32}\end{array}$ & $\begin{array}{l}\mathrm{N}=38, \\
17 \text { casos de LMA e } \\
19 \text { de LLA }\end{array}$ & $\begin{array}{l}\text { Haploidêntico com } \\
\text { depleção de células T }\end{array}$ & $\begin{array}{l}\text { Rec. (LMA e LLA) } \\
\text { de } 54 \%{ }^{*}\end{array}$ & $\begin{array}{l}\text { Rec. (LMA e LLA) } \\
\text { de } 13 \%^{*}\end{array}$ \\
\hline $\begin{array}{l}\text { Bishara et al., } \\
2004^{33}\end{array}$ & $\begin{array}{l}\mathrm{N}=62, \\
15 \text { casos de LMA, } \\
24 \text { casos de LLA, } \\
13 \text { casos de LMC }\end{array}$ & $\begin{array}{l}\text { Haploidêntico com } \\
\text { depleção de células T } \\
\text { menos efetiva }\end{array}$ & $\begin{array}{l}\text { rec. de } 50 \% \text {, } \\
\text { DECH de } 45 \% \%^{*} \text { e } \\
\text { SG de } 19 \%^{*}\end{array}$ & $\begin{array}{l}\text { rec de } 42 \% \text { e } \\
\text { DECH de } 70 \%{ }^{*} \text { e } \\
\text { SG de } 5 \%{ }^{*}\end{array}$ \\
\hline $\begin{array}{l}\text { Davies et al., } \\
2002^{34}\end{array}$ & $\begin{array}{l}\mathrm{N}=175, \\
14 \text { casos de LMA, } \\
35 \text { de LLA, } \\
58 \text { de } \mathrm{LMC}, \\
16 \text { de outras leucemias, } \\
9 \text { SMD e } \\
43 \text { com outras doenças }\end{array}$ & $\begin{array}{l}\text { Não aparentado } \\
\text { com incompatibilidade } \\
\text { de pelo menos } 1 \text { alelo } \\
\text { de HLA-A, B, C } \\
\text { ou DRB1 }\end{array}$ & $\begin{array}{l}\text { DECH de } 50 \% \text {, } \\
\text { rec. de } 12 \% \text { e } \\
\text { SG de } 40 \%\end{array}$ & $\begin{array}{l}\text { DECH de } 61 \% \text {, } \\
\text { rec. de } 9 \% \text { e } \\
\text { SG de } 32 \%\end{array}$ \\
\hline $\begin{array}{l}\text { Giebel et al., } \\
2003^{35}\end{array}$ & $\begin{array}{l}\mathrm{N}=130, \\
22 \text { casos de LMA, } \\
38 \text { de } \mathrm{LLA}, \\
23 \text { de } \mathrm{SMD}, \\
42 \text { de } \mathrm{LMC} \text { e } \\
5 \text { de outras doenças }\end{array}$ & $\begin{array}{l}\text { Não aparentado, } \\
\text { uso de ATG, } \\
\text { HLA idêntico ou com } \\
\text { pequeno grau de } \\
\text { incompatibilidade }\end{array}$ & $\begin{array}{l}\text { SLD de } 39 \%^{*} \text {, } \\
\text { rec. de } 18 \% \text { e } \\
\text { DECH de } 43 \%\end{array}$ & $\begin{array}{l}\text { SLD de } 87 \% * \text {, } \\
\text { rec. de } 0 \% \text { e } \\
\text { DECH de } 30 \%\end{array}$ \\
\hline $\begin{array}{l}\text { Bornhäuser et al., } \\
2004^{36}\end{array}$ & $\begin{array}{l}\mathrm{N}=118, \\
59 \text { casos de LMA, } \\
14 \text { de } S M D \text { e } \\
45 \text { de } L M C\end{array}$ & $\begin{array}{l}\text { Não aparentado, } \\
\text { uso de ATG, } \\
\text { HLA idêntico ou com } \\
\text { pequeno grau de } \\
\text { incompatibilidade }\end{array}$ & $\begin{array}{l}\text { DECH de } 69 \% \text {, } \\
\text { SG de } 55 \% \text { e } \\
\text { rec. de } 35 \%{ }^{*}\end{array}$ & $\begin{array}{l}\text { DECH de } 46 \% \text {, } \\
\text { SG de } 45 \% \text { e } \\
\text { rec. de } 60 \%{ }^{*}\end{array}$ \\
\hline $\begin{array}{l}\text { Beelen et al., } \\
2005^{37}\end{array}$ & $\begin{array}{l}\mathrm{N}=374, \\
138 \text { casos de LMA e } \\
236 \text { de LMC }\end{array}$ & $\begin{array}{l}\text { Não aparentado e } \\
\text { aparentado, } \\
\text { HLA idêntico ou com } \\
\text { pequeno grau de } \\
\text { incompatibilidade }\end{array}$ & $\begin{array}{l}\text { Rec. no HLA-idêntico } \\
\text { de } 22 \% \text { e no não idêntico } \\
\text { de } 18 \% \text {; DECH no } \\
\text { HLA-idêntico de } 39 \%^{*} \text {, } \\
\text { e no não idêntico de } 58 \% \text {; } \\
\text { SLD no HLA-idêntico de } \\
53 \% \text { e no não idêntico } \\
\text { de } 50 \%\end{array}$ & $\begin{array}{l}\text { Rec. de } 5 \%{ }^{*} \\
\text { DECH de } 58 \% \text { e } \\
\text { SLD de } 55 \%\end{array}$ \\
\hline $\begin{array}{l}\text { Hsu et al., } \\
2006^{38}\end{array}$ & $\begin{array}{l}\mathrm{N}=1571, \\
419 \text { casos de LMA, } \\
252 \text { de } \mathrm{SMD} \text { e } \\
900 \text { de } \mathrm{LMC}\end{array}$ & $\begin{array}{l}\text { Não aparentado, } \\
\text { HLA idêntico ou } \\
\text { com pequeno grau } \\
\text { de incompatibilidade }\end{array}$ & $\begin{array}{l}\text { Os autores não } \\
\text { apresentaram os } \\
\text { resultados deste grupo, } \\
\text { apenas o resultado } \\
\text { comparativo entre KIR } \\
\text { incompatível e } \\
\text { KIR compatível } \\
\text { apresentado ao lado. } \\
\text { Resultados em taxa de risco }\end{array}$ & $\begin{array}{l}\text { DECHaguda de 1,10, } \\
\text { DECHcrônica de 1,13, } \\
\text { rec. de } 0,68, \text { MT de } 1,04\end{array}$ \\
\hline $\begin{array}{l}\text { Hsu et al., } \\
2005^{40}\end{array}$ & $\begin{array}{l}\mathrm{N}=178, \\
45 \text { casos de LLA, } \\
57 \text { de } \mathrm{LMA}, \\
61 \text { de } \mathrm{LMC} \text { e } \\
15 \text { de } \text { SMD }\end{array}$ & $\begin{array}{l}\text { Aparentado, } \\
\text { HLA idêntico, } \\
\text { com depleção } \\
\text { de células T }\end{array}$ & $\begin{array}{l}\text { Os autores não } \\
\text { apresentaram os } \\
\text { resultados deste grupo, } \\
\text { apenas o resultado } \\
\text { comparativo entre KIR } \\
\text { incompativel e } \\
\text { KIR compatível } \\
\text { apresentado ao lado. } \\
\text { Resultados em taxa de risco }\end{array}$ & $\begin{array}{l}\text { Grupo de LLA: SG de } 0,73 \text {, } \\
\text { SLD de } 0,78 \text { e rec. de } 1,27 \text {. } \\
\text { Grupo de LMC: SG de } 1,59 \text {, } \\
\text { SLD de } 1,11 \text { e rec de } 0,65 \text {. } \\
\text { Grupo de LMA e SMD: } \\
\text { SG de } 0,53^{*} \text {, SLD de } 0,53^{*} \text { e } \\
\text { rec. de } 0,51^{*}\end{array}$ \\
\hline
\end{tabular}


dência de DECH ou sobrevida livre de doença ${ }^{37}$ (Tabela 2).

Um estudo multicêntrico realizado por Hsu et al ${ }^{38}$ analisou a influência da incompatibilidade KIR em TCTH não aparentado com diferentes graus de incompatibilidade de HLA. Foram estudados 1.571 pacientes com doenças malignas mielóides. Não houve vantagem estatisticamente significativa no grupo de incompatibilidade KIR (Tabela 2). Diferenças no tamanho da amostra, técnicas de transplante e método de detecção de incompatibilidade KIR podem explicar a diferença dos resultados encontrados neste estudo em relação a de outros autores. Houve depleção de células T em apenas $20 \%$ dos casos, e, mesmo assim, com uma eficácia bem menor do que a realizada por Ruggeri et al. ${ }^{14}$ Mais uma vez, a presença de células $\mathrm{T}$ pode ter mascarado a aloreatividade de células NK. Além disso, foi utilizado o modelo ligante-ligante para avaliar a incompatibilidade KIR, que é considerado menos preciso.

No caso do TCTH aparentado, a maioria dos doadores é HLA idêntico aos pacientes. Neste contexto, a chance de disparidade KIR/HLA permanece, mas é muito reduzida em comparação ao transplante haploidêntico ou ao transplante não aparentado. Por isso, Cook et al. ${ }^{39}$ investigaram se em TCTH aparentado HLA idêntico a presença de KIR ativadores no doador poderia afetar de forma significativa a resposta dos pacientes ao transplante. Estes autores observaram que pacientes com doenças mielóides que não tinham alelos de HLA-C pertencentes ao grupo 1 apresentavam uma pior sobrevida relacionada à infecção e à recaída, mas não à $\mathrm{DECH}$. Além disso, este efeito só era observado se o doador carregasse em seu genoma o KIR ativador KIR2DS2, que se acredita que reconheça HLA-C do grupo 1 . O mesmo efeito não era observado em doenças linfóides. Neste estudo, os modelos ligante-ligante ou receptor-ligante não foram acessados de forma direta, pois estes modelos levam em consideração apenas o papel de KIR inibidores, por isso a comparação deste estudo com os de outros autores citados anteriormente fica prejudicada.

Outro grupo estudou o papel da aloreatividade de células NK no TCTH aparentado HLA idêntico com depleção de células T. Este estudo incluía 178 pacientes com doenças hematológicas malignas. A análise do genótipo KIR do doador com HLA do paciente demonstrou que $62,9 \%$ dos pacientes não tinham ligantes de HLA para os KIR inibitórios do doador. Em pacientes com LMA e SMD foi encontrada uma melhora significante na sobrevida global, aumento da sobrevida livre de doença e menor incidência de recaída em pacientes com incompatibilidade KIR com o doador, analisada através do modelo receptor-ligante. Não foi observada nenhuma contribuição significante dos KIR ativadores na resposta destes pacientes. Não foi observado nenhum efeito nos casos de LLA e $\mathrm{LMC}^{40}$ (Tabela 2). Esta melhora na sobrevida e diminuição de riscos de recaída nos casos de LMA e SMD, mas não de LLA, estão de acordo com os resultados encontrados no estudo em TCTH haploidêntico de
Ruggeri et al. ${ }^{14}$ Os resultados encontrados por Hsu et al ${ }^{40}$ diferem dos encontrados por Cook et al. ${ }^{39}$ Isso pode estar relacionado com o fato de Hsu et $a l^{40}$ terem realizado depleção de células T, o que não foi feito no estudo de Cook et al. ${ }^{39}$

\section{Conclusões}

Apesar dos resultados conflitantes, os estudos sobre a incompatibilidade KIR nos diferentes tipos de TCTH levam à sugestão de que pode haver benefícios da aloreatividade das células NK de doador, porém estes benefícios são muito dependentes do protocolo utilizado no transplante. A questão mais importante parece ser a depleção de células $T$, o que pode estar relacionado à omissão ou diminuição do regime profilático da DECH neste tipo de transplante, o que facilita uma reconstituição imunológica rápida e permite os efeitos benéficos da aloreatividade de células NK.

A maioria dos estudos sobre incompatibilidade KIR e TCTH é feita de forma retrospectiva, muitas vezes baseados apenas na genotipagem HLA sem incluir estudos funcionais ou avaliação direta dos receptores KIR presentes nos doadores. A análise direta dos receptores KIR é importante, pois os genes KIR e HLA estão em cromossomos diferentes e segregam de forma independente, ou seja, não se pode prever o genótipo KIR a partir do genótipo HLA. Uma avaliação mais precisa da freqüência real das células NK aloreativas requer o estudo do repertório clonal ou uma combinação de análises fenotípicas e funcionais da população de células NK.

Apesar de vários estudos sobre o assunto, ainda não ficou estabelecido quais tipos de pacientes e quais leucemias teriam maiores benefícios com o potencial aloreativo das células NK, provavelmente devido a diferenças metodológicas. Portanto, há necessidade de novos estudos, em populações maiores e mais homogêneas, incluindo ensaios funcionais, identificação dos subtipos de leucemias mais susceptíveis à atividade NK e avaliação direta do repertório KIR, para verificar de forma mais precisa o papel das células NK e seus receptores KIR no TCTH.

\section{Abstract}

Natural killer (NK) cells were identified over 30 years ago by their ability to kill cancer and virally infected cells without prior sensitization. For years the recognition mechanisms of target cells were unknown, until the 1990s when the "missing-self" hypothesis was proposed. According to this theory, although tolerant to normal autologous cells, NK cells can recognize and attack cells that have down-regulated human leukocyte antigen (HLA) class I molecules. The discovery of killer immunoglobulin-like receptors (KIR) that specifically recognize HLA class I molecules corroborated this hypothesis. These new concepts point to the importance of studying KIR in hematopoietic stem cell transplantation (HSCT). HLA disparities between the donor and patient in HSCT may be distinguished by NK cells leading to alloreactivity. Even though 
there are some promising results, until now existing studies have not reached any consensus. Here, we will review the relevance of NK cells and KIR in the different types of HSC. Rev. bras. hematol. hemoter. 2008;30(4):320-329.

Key words: KIR; NK cells; hematopoietic stem cell transplantation; leukemia.

\section{Agradecimento}

Agradecemos à Dra. Vivian M. Rumjanek pelo incentivo para escrever esta revisão, à Dra. Maria Helena Ornellas de Souza e Dra. Karen Wagner de Souza pela leitura crítica deste artigo. Agradecemos também à Capes e ao Instituto Nacional de Câncer (Inca) - Ministério da Saúde (MS) pelo apoio financeiro.

\section{Referências Bibliográficas}

1. Riddell SR, Berger C, Murata M, Randolph S, Warren EH. The graft versus leukemia response after allogeneic hematopoietic stem cell transplantation. Blood Rev. 2003;17(3):153-62.

2. Kolb HJ, Schmid C, Barrett AJ, Schendel DJ. Graft-versus-leukemia reactions in allogeneic chimeras. Blood. 2004;103(3):767-76.

3. Barrett AJ, Rezvani K, Solomon S, Dickinson AM, Wang XN, Stark $\mathrm{G}$ et al. New developments in allotransplant immunology. Hematology. Hematology Am Soc Hematol Educ Program. 2003: 350-71.

4. Torelli GF, Guarini A, Maggio R, Alfieri C, Vitale A, Foa R. Expansion of natural killer cells with lytic activity against autologous blasts from adult and pediatric acute lymphoid leukemia patients in complete hematologic remission. Haematologica. 2005; 90(6):785-92.

5. Keever CA, Small TN, Flomenberg N, Heller G, Pekle K, Black P et al. Immune reconstitution following bone marrow transplantation: comparison of recipients of T-cell depleted marrow with recipients of conventional marrow grafts. Blood. 1989;73(5):1340-50.

6. Diamond HR, Souza MH, Bouzas LF, Tabak DG, Campos MM, Câmara FP et al. Deficit of T-cell recovery after allogeneic bone marrow transplantation in chronic myeloid leukemia patients. Anticancer Res. 1995;15(4):1553-60.

7. Farag SS, Fehniger TA, Ruggeri L, Velardi A, Caligiuri MA. Natural killer cell receptors: new biology and insights into the graft-versusleukemia effect. Blood. 2002;100(6):1935-47.

8. O'Connor GM, Hart OM, Gardiner CM. Putting the natural killer cell in its place. Immunology. 2006;117(1):1-10.

9. Dines I, Rumjanek VM, Persechini PM. What is going on with natural killer cells in HIV infection? Int Arch Allergy Immunol. 2004;133(4):330-9.

10. Raulet DH. Interplay of natural killer cells and their receptors with the adaptive immune response. Nat Immunol. 2004;5(10):996-1002.

11. Moretta L, Moretta A. Killer immunoglobulin-like receptors. Curr Opin Immunol. 2004;16(5):626-33.

12. Farag SS, Caligiuri MA. Human natural killer cell development and biology. Blood Rev. 2006;20(3):123-37.

13. Ruggeri L, Capanni M, Casucci M, Volpi I, Tosti A, Perruccio K et al. Role of natural killer cell alloreactivity in HLA-mismatched hematopoietic stem cell transplantation. Blood. 1999;94(1):333-9.

14. Ruggeri L, Capanni M, Urbani E, Perruccio K, Shlomchik WD, Tosti A, et al. Effectiveness of donor natural killer cell alloreactivity in mismatched hematopoietic transplants. Science. 2002;295 (5562):2097-100.
15. Velardi A, Ruggeri L, Alessandro, Moretta, Moretta L. NK cells: a lesson from mismatched hematopoietic transplantation. Trends Immunol. 2002;23(9):438-44.

16. Oshimi K, Oshimi Y, Motoji T, Kobayashi S, Mizoguchi H. Lysis of leukemia and lymphoma cells by autologous and allogeneic interferon-activated blood mononuclear cells. Blood. 1983; 61(4):790-8.

17. Yan Y, Steinherz P, Klingemann HG, Dennig D, Childs BH, McGuirk $\mathrm{J}$, et al. Antileukemia activity of a natural killer cell line against human leukemias. Clin Cancer Res. 1998;4(11):2859-68.

18. Pende D, Spaggiari GM, Marcenaro S, Martini S, Rivera P, Capobianco A, et al. Analysis of the receptor-ligand interactions in the natural killer-mediated lysis of freshly isolated myeloid or lymphoblastic leukemias: evidence for the involvement of the Poliovirus receptor (CD155) and Nectin-2 (CD112). Blood. 2005;105(5):2066-73.

19. Asai O, Longo DL, Tian ZG, Hornung RL, Taub DD, Ruscetti FW, et al. Suppression of graft-versus-host disease and amplification of graft-versus-tumor effects by activated natural killer cells after allogeneic bone marrow transplantation. J Clin Invest. 1998; 101 (9):1835-42.

20. JJaksch M, Mattsson J. The pathophysiology of acute graft-versushost disease. Scand J Immunol. 2005;61(5):398-409.

21. Ljunggren HG, Kärre K. In search of the 'missing self': MHC molecules and NK cell recognition. Immunol Today. 1990; 11(7):237-44.

22. Vilches C, Parham P. KIR: diverse, rapidly evolving receptors of innate and adaptive immunity. Annu Rev Immunol. 2002; 20:217-51.

23. Bléry M, Olcese L, Vivier E. Early signaling via inhibitory and activating NK receptors. Hum Immunol. 2000;61(1):51-64.

24. Borrego F, Kabat J, Kim DK, Lieto L, Maasho K, Peña J, et al. Structure and function of major histocompatibility complex (MHC) class I specific receptors expressed on human natural killer (NK) cells. Mol Immunol. 2002 Feb;38(9):637-60.

25. Uhrberg M. The KIR gene family: life in the fast lane of evolution. Eur J Immunol. 2005;35(1):10-5.

26. Carrington, M., Norman, P. The KIR gene cluster. National Library of Medicine, United States of America, NCBI, 2003. Disponível em: $<$ http://www.ncbi.nlm.nih.gov/booksbv.fcgi?rid=mono_003. TOC\&depth=2>. Acesso em 07 mar. 2007.

27. Raulet DH, Vance RE, McMahon CW. Regulation of the natural killer cell receptor repertoire. Annu Rev Immunol. 2001;19:291-330.

28. Witt CS, Christiansen FT. The relevance of natural killer cell human leucocyte antigen epitopes and killer cell immunoglobulinlike receptors in bone marrow transplantation. Vox Sang. 2006; 90(1):10-20.

29. Fernandez NC, Treiner E, Vance RE, Jamieson AM, Lemieux S, Raulet DH. A subset of natural killer cells achieves self-tolerance without expressing inhibitory receptors specific for self-MHC molecules. Blood. 2005;105(11):4416-23.

30. Anfossi N, André P, Guia S, Falk CS, Roetynck S, Stewart CA, et al. Human NK cell education by inhibitory receptors for MHC class I. Immunity. 2006;25(2):331-42.

31. Shilling HG, McQueen KL, Cheng NW, Shizuru JA, Negrin RS, Parham P. Reconstitution of NK cell receptor repertoire following HLA-matched hematopoietic cell transplantation. Blood. 2003; 101(9):3730-40

32. Leung W, Iyengar R, Turner V, Lang $\mathrm{P}$, Bader $\mathrm{P}$, Conn $\mathrm{P}$, et al. Determinants of antileukemia effects of allogeneic NK cells. J J Immunol. 2004;172(1):644-50.

33. Bishara A, De Santis D, Witt CC, Brautbar C, Christiansen FT, Or $\mathrm{R}$, et al. The beneficial role of inhibitory KIR genes of HLA class 
I NK epitopes in haploidentically mismatched stem cell allografts may be masked by residual donor-alloreactive $\mathrm{T}$ cells causing GVHD. Tissue Antigens. 2004;63(3):204-11.

34. Davies SM, Ruggieri L, DeFor T, Wagner JE, Weisdorf DJ, Miller JS, et al. Evaluation of KIR ligand incompatibility in mismatched unrelated donor hematopoietic transplants. Killer immunoglobulin-like receptor. Blood. 2002;100(10):3825-7.

35. Giebel S, Locatelli F, Lamparelli T, Velardi A, Davies S, Frumento $\mathrm{G}$, et al. Survival advantage with KIR ligand incompatibility in hematopoietic stem cell transplantation from unrelated donors. Blood. 2003;102(3):814-9.

36. Bornhäuser M, Schwerdtfeger R, Martin H, Frank KH, Theuser C, Ehninger G. Role of KIR ligand incompatibility in hematopoietic stem cell transplantation using unrelated donors. Blood. 2004; 103(7):2860-1

37. Beelen DW, Ottinger HD, Ferencik S, Elmaagacli AH, Peceny R, Trenschel R, et al. Genotypic inhibitory killer immunoglobulinlike receptor ligand incompatibility enhances the long-term antileukemic effect of unmodified allogeneic hematopoietic stem cell transplantation in patients with myeloid leukemias. Blood. 2005;105(6):2594-600.

38. Hsu KC, Gooley T, Malkki M, Pinto-Agnello C, Dupont B, Bignon $\mathrm{JD}$, et al. KIR ligands and prediction of relapse after unrelated donor hematopoietic cell transplantation for hematologic malignancy. Biol Blood Marrow Transplant. 2006;12(8):828-36.

39. Cook MA, Milligan DW, Fegan CD, Darbyshire PJ, Mahendra P, Craddock CF, et al. The impact of donor KIR and patient HLA-C genotypes on outcome following HLA-identical sibling hematopoietic stem cell transplantation for myeloid leukemia. Blood. 2004;103(4):1521-6.

40. Hsu KC, Keever-Taylor CA, Wilton A, Pinto C, Heller G, Arkun K, et al. Improved outcome in HLA-identical sibling hematopoietic stem-cell transplantation for acute myelogenous leukemia predicted by KIR and HLA genotypes. Blood. 2005;105(12):4878-84.

Avaliação: Editor e dois revisores externos

Conflito de interesse: não declarado

Recebido: 06/11/2007

Aceito: 27/11/2007 